Sains Malaysiana 47(7)(2018): 1557-1562

http://dx.doi.org/10.17576/jsm-2018-4707-25

\title{
Macronutrients and Sugar Content in Foods and Beverages from Three Selected Zones in Peninsular Malaysia
}

(Kandungan Makronutrien dan Gula dalam Makanan dan Minuman dari Tiga Zon Terpilih di Semenanjung Malaysia)

\author{
Rosmawati Dora, Hasnah Haron*, SuZAna Shahar, Chong Ching Phang, \\ MUHAMAD FIKRI MOHD FAUZI \& MOHD FAIRULNIZAL MD NOH
}

\begin{abstract}
This study was conducted to determine the content of macronutrients and sugar in 30 types offood selected from three zones in Peninsular Malaysia. The food samples consisted of 14 types of processed foods and beverages, 8 types of fruits and 10 types ready to eat food. Each type of food and drink were purchased from selected restaurants, stores and supermarkets from three different zones which were North zone (Perak), Central zone (Selangor) and South Zone (Johor). Methods used for proximate analysis were based on the standard methods of AOAC (1997) while the total carbohydrate was calculated by difference method. Total calories were calculated using Atwater method. Total sugar content were analysed using high performace liquid chromatography (HPLC). Dietary fibre contents were determined by using a combination of enzyme-gravimetric methods (AOAC 985.29 and AACC 32-05). The results showed that peanut butter has the highest value of fat $(44.75 \pm 7.59 \mathrm{~g} / 100 \mathrm{~g})$, total calorie $(611 \pm 38 \mathrm{kcal} / 100 \mathrm{~g})$ and dietary fibre contents $(8.07 \pm 0.98$ $\mathrm{g} / 100 \mathrm{~g})$. Highest protein content $(21.98 \pm 2.57 \mathrm{~g} / 100 \mathrm{~g})$ was found in low-fat milk powder. The highest carbohydrate $(97.48 \pm 1.47 \mathrm{~g} / 100 \mathrm{~g})$ and total sugar $(86.7 \pm 2.9 \mathrm{~g} / 100 \mathrm{~g})$ contents were found in palm sugar. The results of this study will update and add up to the data for the Malaysian Food Composition Table and can provide useful information in choosing healthy foods based on the nutrient contents of the food.
\end{abstract}

ABSTRACT

Keywords: Dietary fibre; food composition database; macronutrients; sugar

\section{ABSTRAK}

Kajian ini dijalankan untuk menentukan kandungan makronutrien dan gula dalam 30 jenis makanan yang terpilih dari tiga zon di Semenanjung Malaysia. Sampel makanan tersebut adalah terdiri daripada 14 jenis makanan dan minuman terproses, 8 jenis buah-buahan dan 10 jenis makanan sedia dimakan. Setiap jenis makanan dan minuman telah dibeli daripada restoran, gerai dan pasaraya yang terpilih dari tiga zon berbeza iaitu zon Utara (Perak), zon Tengah (Selangor) dan zon Selatan (Johor). Kaedah yang digunakan untuk analisis proksimat adalah berdasarkan kaedah piawai AOAC (1997) manakala jumlah karbohidrat dihitung secara pembezaan. Jumlah kalori pula dihitung menggunakan kaedah Atwater. Penentuan jumlah gula ditentukan dengan menggunakan kromatografi cecair berprestasi tinggi (HPLC). Kandungan serat diet ditentukan melalui kombinasi kaedah enzim-gravimetrik (AACC 32-05 dan AOAC 985.29). Keputusan kajian menunjukkan kandungan lemak (44.75 $\pm 7.59 \mathrm{~g} / 100 \mathrm{~g})$, jumlah kalori $(611 \pm 38 \mathrm{kcal} / 100 \mathrm{~g})$ dan kandungan serat diet $(8.07 \pm 0.98 \mathrm{~g} / 100 \mathrm{~g})$ yang tertinggi terdapat pada sampel mentega kacang. Kandungan protein yang tertinggi terdapat dalam susu tepung rendah lemak $(21.98 \pm 2.57 \mathrm{~g} / 100 \mathrm{~g})$. Kandungan karbohidrat $(97.48 \pm 1.47 \mathrm{~g} / 100 \mathrm{~g})$ dan jumlah gula $(86.7 \pm 2.9 \mathrm{~g} / 100 \mathrm{~g})$ yang tertinggi terdapat pada sampel gula Melaka. Keputusan kajian ini dapat mengemaskini dan menambah data dalam komposisi zat makanan Malaysia dan dapat memberikan maklumat yang berguna dalam pemilihan makanan yang sihat berdasarkan kandungan nutrien makanan tersebut.

Kata kunci: Gula; makronutrien; pangkalan data komposisi makanan; serat diet

\section{INTRODUCTION}

Nutrients are substance needed in order to carry out the basic function of the body. Nutrient can be classified into macronutrients and micronutrients. Macronutrients are nutrient that are needed in large quantities by the body and can be divided into three categories which are carbohydrate, protein and fat. Micronutrients are nutrients needed in small quantities in the body and can be divided into vitamins and minerals (Eleanor \& Sharon 2008). Sugar is a simple carbohydrate and can be categorized based on monomer unit (Kamal \& Klein 2011). Monosaccharides which have one sugar unit for example glucose, fructose and galactose or disaccharides which have two sugar units such as sucrose, lactose and maltose (Hess et al. 2012).

Based on Malaysian Adult Nutrition Survey (MANS) 2014, energy intake of among Malaysian adults were lower than the recommended nutrient intake. The intake of major micronutrients such as calcium and iron were very low particularly among women. High sugar intake poses a serious public health threat to Malaysians. There is a major 
concern regarding health problem of sugar consumption especially in industrialized era where humans ingest more sugar than before (Clemens et al. 2016). Excessive sugar intake associated with diabetes, dental caries problems and obesity (Amarra et al. 2016; Bray 2013; Malik et al. 2010). Food composition data can be use as dietary guidelines to improve nutritional status of population and used as an important tool to provide data needed to estimate nutrient intake and other dietary components that are required by the body (Elmadfa \& Meyer 2010). The first food composition table was produced in 1818 in the form of scale nutrition by Percy and Vaquelin. The food composition table was then generated following the investigation of the food supply in prison (Somogyi 1974). The food composition table published in Germany in the late 19th century was the first European food composition table that became the basis of the food composition table format until today (Church 2006).

Malaysia Food Composition Database (FCD) was published in 1997 which was almost two decades ago. Malaysia 1997 FCD covered only limited type of foods and nutrient, with sugar and dietary fibre particularly were not included (Malaysia Food Composition Database 2015). Recognizing the importance of etiology and prevention of disease in Malaysia, the existing FCD need to be updated with new data of food and nutrients like sugar and fibre contents. Thus, this study was conducted to determine the content of macronutrients and sugar in thirty types of selected foods and beverages in addition to add and update the data in Malaysia 1997 FCD. This study is part of a larger population based study on older adults in Malaysia, i.e. LRGS TUA (Shahar et al. 2016).

\section{MATERIALS AND METHODS}

\section{FOOD SAMPLING}

In this study, the food samples were collected by stratified random sampling procedure. This approach was the most suitable method for generating food composition database (Greenfield \& Southgate 2003). The food samples were collected from three zones in Peninsular Malaysia which were North zone (Perak), Central zone (Selangor and Kuala Lumpur) and South zone (Johor). Thirty types of foods and beverages were selected based on the list from Ministry of Health (2014) which needs to be updated and added in 1997 FCD (Malaysia Food Composition Database 2015). The samples of the analysis include ready to eat foods $(n=10)$, processed food $(n=8)$, beverages $(n=4)$ and fruits $(n=8)$. Ready to eat foods were purchased from selected restaurants or stores from each zone. Three different brands of processed food and beverages were purchased in Central zone (Kuala Lumpur). Fruits were purchased from three stalls for each type of fruit in Central zone (Kuala Lumpur). The collected samples were confirmed to represent varieties of brands consumed and available nationwide.

\section{SAMPLE PREPARATION}

The foods and beverages samples were purchased, photographed, weighed and measurement were recorded. The samples were homogenized using a blender (Breville, USA) and stored in airtight container. The samples were then dried by using freeze drying method (Martin Christ, Germany). Each sample was labelled accordingly and stored at refrigerator $\left(4^{\circ} \mathrm{C}\right)$ until ready for analysis. Determination of total water content must be carried out prior to freeze drying of the samples.

\section{PROXIMATE ANALYSIS}

The method used was based on the Association of Official Analytical Chemist (AOAC 1997) method of analysis to determine total water content, crude protein content, crude fat content, total ash and total fibre. Energy was calculated based on Atwater general factor and reported in Kcal unit (Atwater \& Bryant 1900). Total water content was determined using a moisture analyzer (Sortorius, Germany). Crude protein content was analysed using Kjehdahl method. Crude fat content was determined using Soxhlet method. The carbohydrate content of the samples was calculated by differences [100 - (ash + moisture + protein + fat)] (Food and Agriculture Organization 1998). Total fibre of the samples was analysed using combination method of AOAC 985-29 and AACC 32-05. Determination of ash was carried out using dry ashing method. All proximate analyses were carried out using six replicates of sample.

\section{SUGAR ANALYSIS}

Total sugar content was determined by using high performance liquid chromatography (HPLC) with Refractive Index Detector (Waters, USA). Extraction of sugar from samples was carried out using solvent based method (acetonitrile: deionized water (50:50 v:v) described by Wills et al. (1980). Sample separation were carried out using the amino-bonded column with a mobile phase consisting of acetonitrile:deionized water: triethylamine in ratio of 75:25:0.2. Sugar content was determined based on the standard solution in series concentration of $0.1,0.2,0.5,0.8$ and $1.0 \mathrm{ppm}$. Quality control samples (biscuits and cordial) were used and analysed simultaneously following standards calibration. This was carried out prior to samples analysis to ensure the reliability of the data. Samples were analysed in duplicates.

\section{STATISTICAL ANALYSIS}

The data obtained from the analysis were analysed using IBM SPSS Statistics for Windows, Version 23.0 (Armonk, NY: IBM Corp.) and Microsoft Excel 2013. The data were expressed by means \pm standard deviation from six replicates samples. Comparison of means in the samples was performed by one way ANOVA. 


\section{RESULTS AND DISCUSSION}

\section{CRUDE PROTEIN CONTENT}

Table 1 shows the crude protein content in 30 types of foods and beverages. Peanut butter $(12.04 \pm 1.68 \mathrm{~g} / 100 \mathrm{~g})$ has the highest crude protein content of processed foods. Peanuts are good source of plant protein (Brufau et al. 2006). Protein content of low-fat milk powder $(21.98 \pm 2.57 \mathrm{~g} / 100$ g) was the highest for drinks. Milk contained two types of protein which were whey and casein. Both proteins contained all the essential amino acids that are sufficient to support the various roles of proteins in the body (Bos 2000; Philips 2009). Crude protein content in fruits samples was lower as compared to other food samples. Study by Slavin and Lloyd (2012) reported that fruits contained low protein content. Longan $(1.37 \pm 0.19 \mathrm{~g} / 100 \mathrm{~g})$ recorded the highest value of protein in fruits samples. For ready to eat food, the sample contained highest crude protein was paratha bread with egg $(7.84 \pm 2.94 \mathrm{~g} / 100 \mathrm{~g})$. High protein content in paratha bread with egg may due to the fact that eggs are a good source of protein other than meat and poultry (NCCFN 2005).

\section{CRUDE FAT CONTENT}

Peanut butter $(44.75 \pm 7.59 \mathrm{~g} / 100 \mathrm{~g})$ contained the highest crude fat content among processed foods as shown in Table 1 . The amount of fat in peanut butter was high especially the monounsaturated fat (Ros \& Mataix 2006). Full cream milk powder $(22.37 \pm 2.50 \mathrm{~g} / 100 \mathrm{~g})$ showed the highest content of crude fat for drinks. Crude fat content in fruits samples were lower as compared to other food samples which was less than $1 \mathrm{~g} / 100 \mathrm{~g}$. Fruits generally have high water content and low fat content (Slavin \& Lloyd 2012). Mangosteen contained the highest crude fat content $(0.62$ $\pm 0.19 \mathrm{~g} / 100 \mathrm{~g})$. Fried noodles have the highest crude fat $(10.60 \pm 2.47 \mathrm{~g} / 100 \mathrm{~g})$ content of ready to eat foods. Ready to eat foods that used frying methods contained higher fat content than the one that used boiling method. During frying, heat is transferred from the heated oil to food (Erdogdu \& Dejmek 2010). Heat and mass transfer occur simultaneously in which the water evaporated from food and oil transferred into the food (Krokida et al. 2000). The transferred of oil into the food increase the fat content in the food.

\section{TOTAL CARBOHYDRATES CONTENT}

The highest amount of carbohydrates for processed food was palm sugar $(97.48 \pm 1.47 \mathrm{~g} / 100 \mathrm{~g})$ as shown in Table 1 . The highest amount of carbohydrates for drinks was premix coffee ( 3 in 1$)$ powder $(80.88 \pm 4.40 \mathrm{~g} / 100 \mathrm{~g})$. The amount of carbohydrate for fruits were almost the same which were in the range of 10 to $20 \mathrm{~g} / 100 \mathrm{~g}$. This was because the major components in the fruit are sugar and fibre (Slavin \& Lloyd 2012). Rambutan (20.36 \pm $0.82 \mathrm{~g} / 100 \mathrm{~g}$ ) had the highest amount of carbohydrates. Plain paratha bread $(55.42 \pm 4.31 \mathrm{~g} / 100 \mathrm{~g})$ had the highest value of carbohydrates for ready to eat food. Plain paratha bread and noodles use the same basic ingredient which is flour; however there was a difference in the amount of carbohydrates. Different types of wheat have different content of carbohydrates and it affects the carbohydrate content in the food (Berrios et al. 2010). Moreover, the difference in ingredients used also affect the carbohydrate content in foods.

\section{TOTAL CALORIES CONTENT}

The highest number of calories for processed food was peanut butter $(611 \pm 38 \mathrm{kcal} / 100 \mathrm{~g})$. The high fat content in peanut butter contributed $66 \%(403 \mathrm{kcal} / 100 \mathrm{~g})$ of total calorie in peanut butter. Full cream milk contained the highest amount of calories for drinks (482 \pm 14 $\mathrm{kcal} / 100 \mathrm{~g}$ ). The fat and carbohydrate contents were the main contributor of calories in full cream milk powder, each nutrient provided $41 \%$ (201 kcal/100 g) and $43 \%$ $(205 \mathrm{kcal} / 100 \mathrm{~g})$ of the total calories, respectively. Total calories for eight type of fruits was less than $100 \mathrm{kcal} / 100$ $\mathrm{g}$. This is due to the fact that fruits generally contain low calorie (Hornick \& Weiss 2011). Mangosteen (88 \pm 2 $\mathrm{kcal} / 100 \mathrm{~g})$ and rambutan $(88 \pm 3 \mathrm{kcal} / 100 \mathrm{~g})$ showed the same amount of calories which were the highest for fruit samples. The carbohydrate content was the major contributor to the total calories of mangosteen (80 $\mathrm{kcal} / 100 \mathrm{~g})$ and rambutan $(82 \mathrm{kcal} / 100 \mathrm{~g})$, which were more than $90 \%$ of total calories. Plain paratha bread (339 $\pm 11 \mathrm{kcal} / 100 \mathrm{~g}$ ) contain the highest number of calories for ready to eat food. High carbohydrate content was the main contributor of calories in plain paratha bread which was $65 \%(222 \mathrm{kcal} / 100 \mathrm{~g})$ of the total calories.

\section{TOTAL SUGAR CONTENT}

Table 1 shows that palm sugar $(86.7 \pm 2.9 \mathrm{~g} / 100 \mathrm{~g})$ contained highest total sugar compared to other samples in processed foods. Palm sugar is produced by extracting the sap from the flower bud of a coconut tree and used as a sweetener in some dishes especially in local desserts in Southeast Asia (Ishak et al. 2013). Sugar content stated on the packaging of the premix coffee ( 3 in 1) powder product also showed high amount of total sugar (53.5 $\mathrm{g} / 100 \mathrm{~g}$ ), which was parallel to this study. It is advised to take premix coffee ( 3 in 1 ) powder prudently due to the high sugar content that can cause adverse health effects such as obesity, type 2 diabetes and heart disease (Malik \& Hu 2015; Malik et al. 2010). Rambutan (17.9 \pm 0.5 $\mathrm{g} / 100 \mathrm{~g}$ ) showed the highest total sugar compared to other fruits samples. Plain paratha bread $(4.5 \pm 3.6 \mathrm{~g} / 100 \mathrm{~g})$ contains the highest total sugar for ready to eat food. The ingredients used in making paratha bread are flour, water and salt, then mixed and kneaded to form dough before shaping by hand and cooked. High total sugar content in paratha bread may due to the added sugar when preparing the paratha bread. 


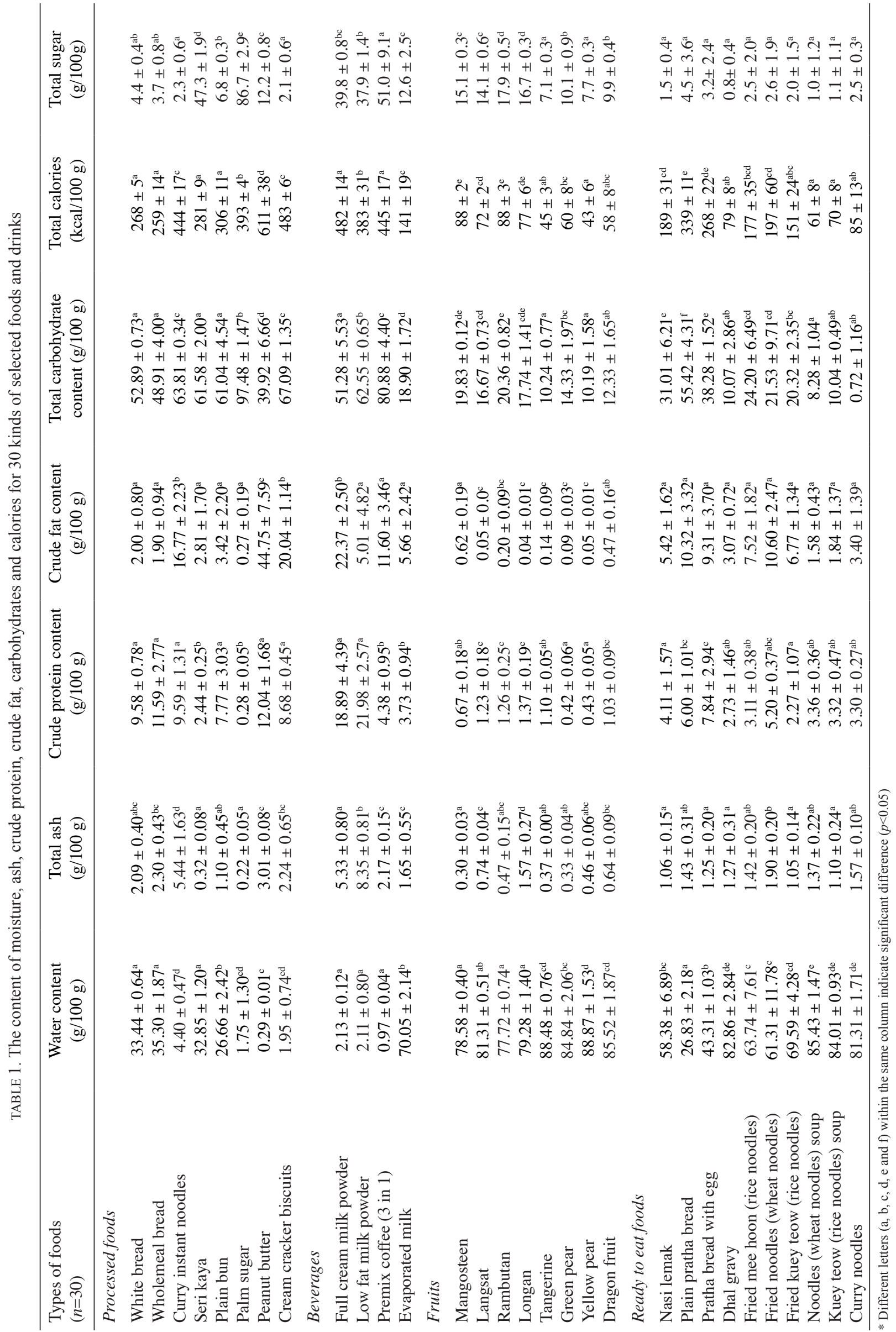




\section{TOTAL DIETARY FIBRE CONTENT}

Table 2 shows total fibre content in ten types of food. Peanut butter $(8.07 \pm 0.98 \mathrm{~g} / 100 \mathrm{~g})$ showed the highest amount of dietary fibre, followed by wholemeal bread $(6.07 \pm 1.27 \mathrm{~g} / 100 \mathrm{~g})$, dhal gravy $(3.93 \pm 0.39 \mathrm{~g} / 100 \mathrm{~g})$ and white bread $(3.64 \pm 0.4 \mathrm{~g} / 100 \mathrm{~g})$. According to Liu (2002), the fibre content in beans and legumes are high and the major source of soluble fibre. The content of fibre in dhal gravy was lower than peanut butter may due to the difference in water content. Dhal gravy consist of $82.86 \%$ of water compared to peanut butter that consist only $0.29 \%$ of water. Therefore, the high content of peanut in peanut butter than the content of legumes in dhal gravy contributes to high content of fibre in peanut butter. Koh-Banerjee et al. (2004) reported that the fibre content is high in whole meal food which due to the bran that was separated during processing. Cream cracker biscuits $(3.14 \pm 0: 53 \mathrm{~g} / 100 \mathrm{~g})$ and green pear $(3.21 \pm 0.07 \mathrm{~g} / 100 \mathrm{~g})$ contained almost the same amount of dietary fibre. The amount of dietary fibre of mangosteen $(2.36 \pm 0.47 \mathrm{~g} / 100 \mathrm{~g})$, dragon fruit $(2.01 \pm 0.06 \mathrm{~g} / 100 \mathrm{~g})$, yellow pear $(1.78 \pm 0.05 \mathrm{~g} / 100 \mathrm{~g})$ and oranges $(1.71 \pm 0.16 \mathrm{~g} / 100 \mathrm{~g})$ were almost the same. Fruits are usually recommended as a source of dietary fibre because fruit is a good source of fibre (Hornick \& Weiss 2011; Slavin \& Lloyd 2012).

TABLE 2. Total dietary fibre content of ten types foods

\begin{tabular}{lc}
\hline Type of foods & Mean $(\mathrm{g} / 100 \mathrm{~g}) \pm \mathrm{SD}$ \\
\hline Mangosteen & $2.36 \pm 0.47^{\mathrm{a}}$ \\
Peanut butter & $8.07 \pm 0.98^{\mathrm{c}}$ \\
Wholemeal bread & $6.07 \pm 1.27^{\mathrm{bc}}$ \\
Dhal gravy & $3.93 \pm 0.39^{\mathrm{ab}}$ \\
Dragon fruit & $2.01 \pm 0.06^{\mathrm{a}}$ \\
Tangerine & $1.71 \pm 0.16^{\mathrm{a}}$ \\
White bread & $3.64 \pm 0.4^{\mathrm{a}}$ \\
Cream cracker biscuits & $3.14 \pm 0.53^{\mathrm{a}}$ \\
Green pear & $3.21 \pm 0.07^{\mathrm{a}}$ \\
Yellow pear & $1.78 \pm 0.05^{\mathrm{a}}$ \\
\hline
\end{tabular}

* Different letters $(\mathrm{a}, \mathrm{b}$ and $\mathrm{c}$ ) within the same column indicate significant difference $(p<0.05)$

\section{CONCLUSION}

The study on the contents of macronutrients in 30 types of food showed that peanut butter contained highest total fat, calories and fibre contents. Low-fat milk powder had the highest protein content whilst palm sugar had the highest total carbohydrate and total sugar contents. The results of this study will add up and update to the data for the Malaysian Food Composition Database and can provide useful information in choosing healthy foods based on the nutrient contents of the food.

This study has highlighted the macro nutritional values, inclusive of sugar and fiber of selected foods and beverages commonly available from three zones of Peninsular Malaysia using standard methods. However, this study only covers three zones and only total sugar was reported. There is a need to embark on a larger scale study involving other zones in Malaysia and also in-depth study of the types of sugars and fatty acids.

\section{ACKNOWLEDGEMENTS}

The authors would like to acknowledge the Ministry of Education, Malaysia for the grant (FRGS/1/2016/SKK06/ UKM/01/1) and The Institute for Medical Research, Kuala Lumpur for allowing the usage of HPLC instrument in this study.

\section{REFERENCES}

AOAC. 1997. Official Methods of Analysis of AOAC International. $16^{\text {th }}$ ed. Association of Official Analytical Chemists: Washington D.C.

Amarra, M.S., Khor, G.L. \& Chan, P. 2016. Intake of added sugar in Malaysia: A Review. Asia Pac. J. Clin. Nutr. 25(2): 227-240.

Atwater, W.O. \& Bryant, A.P. 1900. The availability and fuel value of food materials. Agricultural Experiment Stations 12th Annual Report 1899. pp. 73-110.

Bos, C. 2000. Nutritional and physiological criteria in the assessment of milk protein quality for humans. The Journal of American College Nutrition 19(2): 191-205.

Berrios, J.D.J., Morales, P., Camara, M. \& Sanchez-Mata, M.C 2010. Carbohydrate composition of raw and extruded pulse flours. Food Research International 43(2): 531-536.

Bray, G.A. 2013. Energy and fructose from beverages sweetened with sugar or high-fructose corn syrup pose a health risk for some people. Advances in Nutrition: An International Review Journal 4(2): 220-225.

Brufau, G., Boatella, J. \& Rafecas, M. 2006. Nuts: Source of energy and macronutrients. British Journal of Nutrition 96(2): 24-28.

Church, S.M. 2006. The history of food composition database. British Nutrition Bulletin 31(1): 15-20.

Clemens, R.A., Jones, J.M., Kern, M., Lee, S.Y., Mayhew, E.J., Slavin, J.L. \& Zivanovic, S. 2016. Functionality of sugars in foods and health. Comprehensive Reviews in Food Science and Food Safety 15(3): 433-470.

Eleanor, N.W. \& Sharon, R.R. 2008. Understanding Nutrition. Belmont: Thomson Wadsworth.

Elmadfa, I. \& Meyer, A.L. 2010. Importance of food composition data to nutrition and public health. European Journal of Clinical Nutrition 64: 4-7.

Erdogdu, F. \& Dejmek, P. 2010. Determination of heat transfer coefficient during high pressure frying of potatoes. Journal of Food Engineering 96(4): 528-532.

Food and Agriculture Organization (FAO). 1998. Carbohydrates in human nutrition. FAO Food and Nutrition Paper. p. 66.

Greenfield, H. \& Southgate, D.A.T. 2003. Food Composition Data: Production, Management and Use. FAO: Rome.

Hess, J., Latulippe, M.E., Ayoob, K. \& Slavin, J. 2012. The confusing world of dietary sugars: Definitions, intakes, food sources and international dietary recommendations. Food \& Function 3(5): 477-486.

Hornick, B.A. \& Weiss, L. 2011. Comparative nutrient analysis of commonly consumed vegetables. Nutrition Today 46: 130-137.

Ishak, M., Sapuan, S., Leman, Z., Rahman, M., Anwar, U. \& Siregar, J. 2013. Sugar palm (Arenga pinnata): Its fibres, 
polymers and composites. Carbohydrate Polymers 91(2): 699-710.

Kamal, M.A. \& Klein, P. 2011. Determination of sugars in honey by liquid chromatography. Saudi Journal of Biological Sciences 18(1): 17-21.

Koh-Banerjee, P., Franz, M., Sampson, L., Liu, S., Jacobs, J.D.R., Spiegelman, D., Willett, W. \& Rimm, E. 2004. Changes in whole-grain, bran, and cereal fiber consumption in relation to 8-y weight gain among men. Journal of Clinical Nutrition 80(5): 1237-1245.

Krokida, M.K., Oreopoulou, V. \& Maroulis, Z.B. 2000. Water loss and oil uptake as a function of frying time. Journal of Food Engineering 44(1): 39-46.

Liu, S. 2002. Intake of refined carbohydrates and whole grain foods in relation to risk of type 2 diabetes mellitus and coronary heart disease. The Journal of American College Nutrition. 21(4): 298-306.

Malaysian Food Composition Database. 2015. History of Food Composition Database. http://myfcd.moh.gov.my/index.php/ about-us/history-of-food-composition-database. Accessed on 16 September 2016.

Malik, V.S. \& Hu, F.B. 2015. Fructose and cardiometabolic health: What the evidence from sugar-sweetened beverages tells us. Journal of American College of Cardiology 66(14): 1615-1624.

Malik, V.S., Popkin, B.M., Bray, G.A., Després, J.P. \& Hu, F.B. 2010. Sugar-sweetened beverages, obesity, type 2 diabetes mellitus, and cardiovascular disease risk.Circulation 121(11): 1356-1364.

Ministry Health Report of Seminar on Finding of MANS. 2014. Volume 2: Survey Findings

Ministry Health Report of Seminar on Finding of MANS. 2014. Volume 3: Food Consumption Statistics of Malaysia.

Phillips, S.M. 2009. The role of milk- and soy-based protein in support of muscle protein synthesis and muscle protein accretion in young and elderly persons. The Journal of American College Nutrition 28(4): 343-354.

Ros, E. \& Mataix, J. 2006. Fatty acid composition of nuts implications for cardiovascular health. British Journal of Nutrition 96(2): 29-35.
Slavin, J.L. \& Lloyd, B. 2012. Health benefits of fruits and vegetables. An International Review Journal 3(4): 506-516.

Somogyi, J.C. 1974. National food composition tables. In Guidelines for the Preparation of Tables of Food Composition. Karger: Basel: DAT Southgate edition.pp. 1-5.

Wills, R., Balmer, N. \& Greenfield, H. 1980. Composition of Australian foods. 2. Methods of analysis. Food Technology in Australia 32(4): 198-204.

Rosmawati Dora, Hasnah Haron* \& Muhamad Fikri Mohd Fauzi Nutritional Science Programme

Centre of Healthy Ageing \& Wellness

Faculty of Health Sciences

Universiti Kebangsaan Malaysia

Jalan Raja Muda Abdul Aziz

50300 Kuala Lumpur, Federal Territory

Malaysia

Suzana Shahar, Chong Ching Phang

Dietetics Programme

Centre of Healthy Ageing \& Wellness

Faculty of Health Sciences

Universiti Kebangsaan Malaysia

Jalan Raja Muda Abdul Aziz

50300 Kuala Lumpur, Federal Territory

Malaysia

Mohd Fairulnizal Md Noh

Cardiovascular, Diabetes \& Nutrition Research Centre (CDNRC) Institute for Medical Research

50588 Kuala Lumpur, Federal Territory

Malaysia

*Corresponding author; email: hasnaharon@ukm.edu.my

Received: 5 October 2017

Accepted: 27 February 2018 